\title{
Comparing model sensitivities of different landscapes using the ecohydrological SWAT model
}

\author{
B. Schmalz and N. Fohrer \\ Dept. Hydrology and Water Resources Management, Ecology Centre, Kiel University, Germany \\ Received: 22 January 2009 - Revised: 17 April 2009 - Accepted: 28 April 2009 - Published: 12 August 2009
}

\begin{abstract}
Lowland areas are characterised by specific properties, such as flat topography, low hydraulic gradients, shallow groundwater, and high potential for water retention in peatland and lakes. The investigated mesoscale catchments Stör, Treene and Kielstau are located in Northern Germany within lowland areas. Covering areas from 50 to $517 \mathrm{~km}^{2}$, these rural catchments have sandy, loamy and peaty soils and are drained in high fraction by open ditches and tile drainage. Using the river basin model SWAT, sensitivity analyses were carried out through an automatic routine that is based on the Latin-Hypercube (LH) and a One-factor-At-a-Time (OAT) sampling. The objective of this study is to investigate how specific landscape features influence the model behaviour. There are two research questions: a) What are the most sensitive parameters in the studied lowland catchments? b) What differences occur between these landscape features in comparison to mountainous or low mountain range catchments?

The results show that groundwater and soil parameters were found to be most sensitive in the studied lowland catchments and they turned out to be the most influential factors on simulated water discharge. The most sensitive parameter was the threshold water level in shallow aquifer for baseflow (GWQMN). In contrast, many studies of mountainous or low mountain range catchments show that the most sensitive parameters were the surface runoff parameters.
\end{abstract}

\section{Introduction}

Lowland areas are characterised by specific properties, such as flat topography and low hydraulic gradients. Shallow groundwater results in intensive groundwater-stream water interactions (Sophocleous, 2002; Schmalz et al., 2008a).

Correspondence to: B. Schmalz (bschmalz@hydrology.uni-kiel.de)
Furthermore, in these areas there is high potential for water retention in peatland (Kieckbusch et al., 2006) and lakes. In addition, the natural catchment water balance has been changed substantially in most areas by human impacts, such as river regulation, pumping stations, and drainage systems like tile drainage and open ditches. The removal of surplus water causes a drawdown of the groundwater level as well as changed water movement.

To answer questions related to land use and water management, mesoscale hydrological and ecohydrological models can be useful tools. Water balance and water quality of a catchment can be modelled based on climatic data, topographical, soil and land use parameters. Ecohydrological models have already been used successfully in lowland catchments (e.g. Schmalz et al., 2007; Habeck et al., 2005; Hattermann et al., 2006, 2008; Hesse et al., 2008; Krause and Bronstert, 2007; Krause et al., 2007a, b).

Model parameters exerting the most influence on model results are often identified through a sensitivity analysis. Generally, the purpose of a sensitivity analyses is to determine which input parameters exert the most influence on model results. This information allows for insensitive parameters to be eliminated and provides direction for further research in order to reduce parameter uncertainties and increase model accuracy (Hamby, 1994).

The dominant hydrological characteristics and processes of the studied lowland catchments were already identified by field experiments and analyses (Schmalz et al., 2007, 2008a, b; Fohrer et al., 2007). In this study we investigate how these specific properties influence the model behaviour. The studied lowland catchments serve as a reference and shall be compared to studies of other landscapes as mountainous or low mountain range catchments. Therefore an ecohydrological model was used, mainly by means of sensitivity analyses. There are two research questions:

Published by Copernicus Publications on behalf of the European Geosciences Union. 


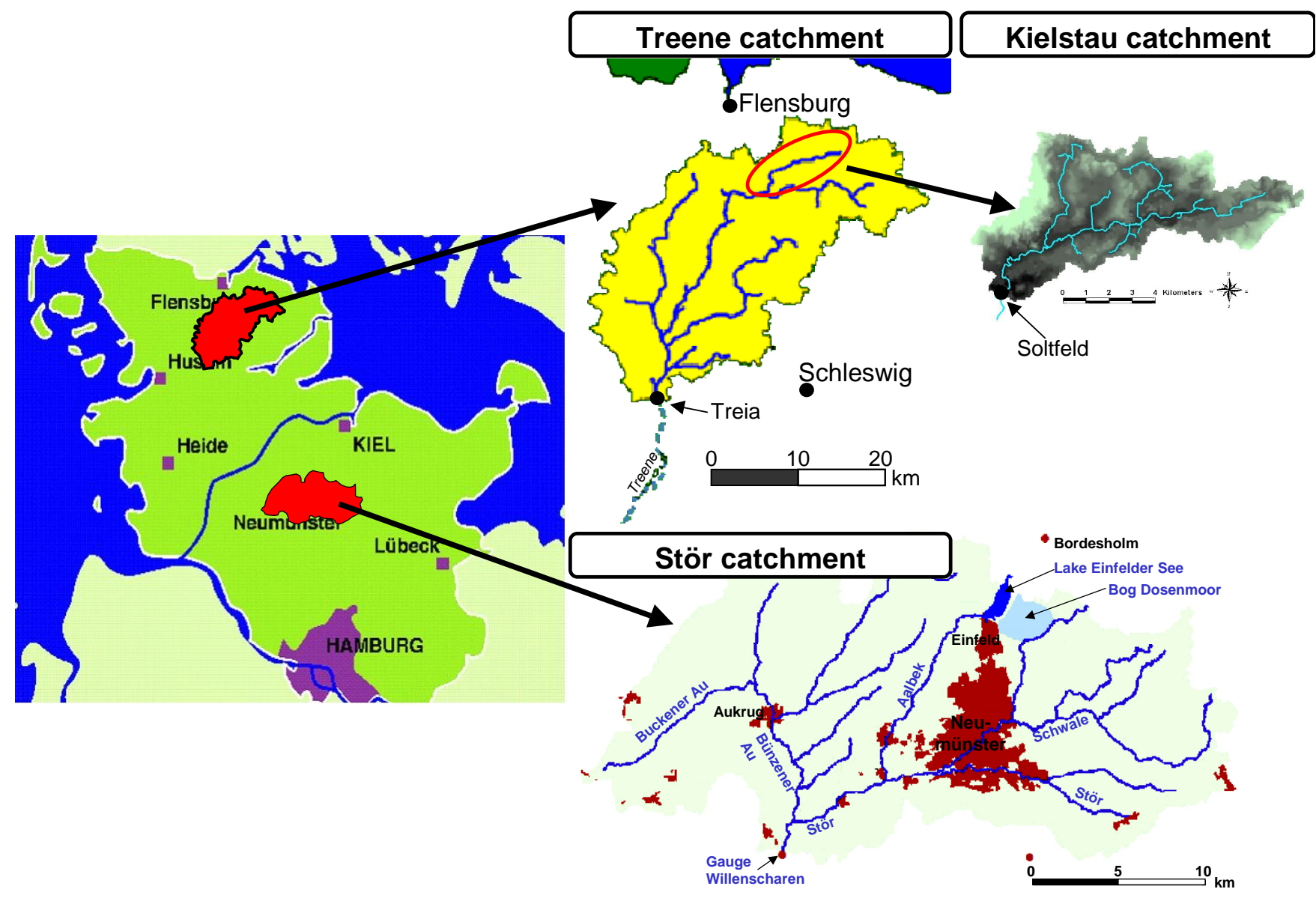

Fig. 1. Location of the three investigated lowland catchments in Northern Germany.

- What are the most sensitive parameters in the studied lowland catchments?

- What differences occur between these landscape features in comparison to mountainous or low mountain range catchments?

\section{Materials and methods}

\subsection{Investigation areas}

The mesoscale investigation sites are parts of a lowland area of Schleswig-Holstein located in Northern Germany. Sandy and loamy soils are characteristic for these catchments with peat soil along the river courses. Land use is dominated by arable land and grassland in different proportions. We examined three catchment areas (Fig. 1), which cover different scales.

The Stör catchment $\left(468 \mathrm{~km}^{2}, 25 \mathrm{~km}\right.$ river length): The upper part of the Stör catchment to the gauge Willenscharen was analysed. The slope of the central model area is small: falling from $90 \mathrm{~m}$ and $60 \mathrm{~m}$ in the western and eastern parts, respectively, to $2 \mathrm{~m}$ a.m.s.l. at the outlet. Only the southwestern region has gradients of more than $3^{\circ}$; but in most of the catchment it is usually smaller than $1^{\circ}$ (LVA S-H, 1995). The precipitation is $831 \mathrm{~mm} /$ year and the mean annual temperature is $8.3^{\circ} \mathrm{C}$. There are mainly sandy soils, few peat soils at the river valleys (fen) and depressions (bog) and Gleysols in the eastern parts. The largest tributaries of the Stör are the Schwale and the Bünzener Au. About $44 \%$ of the area drains into the Bünzener Au (Dobslaff, 2005). The investigation area contains some small ponds and lakes. The larger lake Einfelder See drains into the Stör via the tributary Aalbek. There is significant additional water storage in the Dosenmoor bog ( $575 \mathrm{ha}$ ). The landscape is characterised by numerous drainage networks. For the Buckener Au catchment, Venohr (2000) estimated that the sub-catchment area drained by open ditches and drainage pipes varies from 32 to $40 \%$.

Treene catchment $\left(517 \mathrm{~km}^{2}, 60 \mathrm{~km}\right.$ river length): The watershed that drains into the river between the source and the catchment outlet at the gauge Treia was analysed. The maximum height difference is $76 \mathrm{~m}$. Average precipitation is $872 \mathrm{~mm} /$ year and the mean annual temperature $8.2^{\circ} \mathrm{C}$. The Bondenau and Kielstau are the source rivers of the Treene. 
Both flow into Lake Treßsee, where the Treene has its origin. Large areas of the catchment are drained by open ditches. Larger tributaries to the Treene up to Treia are the Jerrisbek, the Bollingstedter Au and the Jübek. There are three larger lakes: Sankelmarker See $\left(0.56 \mathrm{~km}^{2}\right)$, Südensee $\left(0.64 \mathrm{~km}^{2}\right)$ and Treßsee $\left(0.17 \mathrm{~km}^{2}\right)$ (Dey, 2004).

Kielstau catchment $\left(50 \mathrm{~km}^{2}, 17 \mathrm{~km}\right.$ river length): In a nested approach, we also examined the Kielstau catchment, a sub-catchment of the Treene. The River Kielstau flows through the Lake Winderatter See and has two tributaries from the north, the Moorau and the Hennebach. Various smaller tributaries and water from drainage pipes and open ditches flow into the Kielstau. The drained fraction of the Kielstau catchment is estimated to be approx. 38\% (Fohrer et al., 2007). The Kielstau has been changed markedly from its natural course. The gauge Soltfeld is situated at the catchment outlet. The maximum height difference is about $50 \mathrm{~m}$.

\subsection{Ecohydrological modelling}

\subsubsection{The SWAT model}

The river basin model SWAT (Soil and Water Assessment Tool, Arnold et al., 1998) was used in order to assess the water balance in these complex hydrological catchment areas. The SWAT model is a semi-distributed, process-oriented model for simulating water, nutrient and pesticide transport. The hydrologic simulation is based on the water balance equation and thus represented by interception, evapotranspiration, surface runoff, infiltration, soil percolation, lateral flow, groundwater flow and channel routing processes. Simulations are conducted for mesoscale catchments, subbasins and their hydrological response units (HRU; hydrotopes). The hydrotopes are defined by a unique land use and soil combination within each sub-basin and for the new version with ArcGIS by land use-soil-topography combinations. The advantages of SWAT include the possibility to perform spatially differentiated analyses, to investigate seasonal dynamics, to analyse land use changes and different management practices on water, sediment and nutrients.

For this study, we worked with AVSWAT_2000 (Neitsch et al., 2002a, b) with the ArcView3.x interface (Di Luzio et al., 2002) as well as with SWATX_2005 (Neitsch et al., 2005) with the ArcGIS 9.x (Table 1) and used daily time steps.

Considering lowland catchments, the influence of shallow groundwater is important for the hydrology in the basin. SWAT simulates two aquifers in each subbasin. The shallow aquifer is an unconfined aquifer that contributes to flow in the main channel or reach of the subbasin. The deep aquifer is a confined aquifer (Neitsch et al., 2005).

The water balance for the shallow aquifer considers the water stored in the shallow aquifer, the recharge and groundwater or base flow. Recharge is defined by the amount of recharge entering the aquifer, the total amount of water exiting the bottom of the soil profile and the delay time of the overlying geologic formations (GW_DELAY). A fraction of the total daily recharge can be routed to the deep aquifer. The amount of water moving from the shallow aquifer due to percolation into the deep aquifer is correlated to the aquifer percolation coefficient (RCHRG_DP) and the amount of recharge entering both aquifers (Neitsch et al., 2005).

The shallow aquifer contributes base flow to the main channel or reach within the subbasin. Base flow is allowed to enter the reach only if the amount of water stored in the shallow aquifer exceeds a threshold value specified by the user, GWQMN. The baseflow recession constant ALPHA_BF is a direct index of groundwater flow response to changes in recharge.

SWAT models the movement of water into overlying unsaturated layers as a function of water demand for evapotranspiration, termed "revap". E.g., this process is significant in watershed where the saturated zone is not very far below the surface. The maximum amount of water that will be removed from the aquifer via revap is correlated by the revap coefficient (GW_REVAP) and the potential evapotranspiration (Neitsch et al., 2005).

\subsubsection{Parameterisation of the model}

The ecohydrological modelling with SWAT was conducted by dividing the three study catchments into sub-catchments and hydrotopes (Table 1). The two different Kielstau set-ups vary in different calibration periods and spatial discretisation.

All catchments are characterised by the following properties:

- sandy and loamy soils; peat soils in the riparian wetlands

- land use: mainly arable land and grassland

- artificial drainage

Table 1 shows also the references to the application of SWAT for the three catchments.

\subsubsection{Sensitivity analysis}

AVSWAT_2000 had not implemented an automatic routine for sensitivity analysis yet. So for the Stör and Treene catchments the most sensitive parameters for the model set-ups were assessed in a manual sensitivity analysis. This was performed by changing specific parameters within their allowable range. One parameter at a time was adjusted, while the others were kept unchanged.

Using SWATX_2005, sensitivity analyses were carried out through an automatic routine developed for the SWAT model (van Griensven et al., 2006) that works on the basis of LatinHypercube (LH) simulations and a One-factor-At-a-Time (OAT) sampling. The LH-OAT sensitivity analysis ensures that the full range of all parameters is sampled while every 
94 B. Schmalz and N. Fohrer: Comparing model sensitivities of different landscapes using the ecohydrological SWAT model

Table 1. Model set-ups and references of the three studied lowland catchments.

\begin{tabular}{lllll}
\hline & Stör & Treene & Kielstau I & Kielstau II \\
\hline Size $\left[\mathrm{km}^{2}\right]$ & 468 & 517 & 50 & 50 \\
SWAT version, GIS interface & 2000 , ArcView3.x & 2000, ArcView3.x & 2005, ArcGIS9.x & 2005, ArcGIS9.x \\
Sub-catchments & 22 & 58 & 17 & 8 \\
Hydrotopes & 298 & 681 & 534 & 154 \\
References & Dobslaff, 2005; & Dey, 2004; & Kiesel et al., 2008 & Lam et al., 2008, 2009 \\
& Schmalz et al., 2008b & Dey et al., 2004; & & \\
& & Schmalz et al., 2008b & & \\
\hline
\end{tabular}

Table 2. Model performances of the lowland set-ups (calibration periods: different time scales).

\begin{tabular}{lcc}
\hline catchment & Calibration period & Nash-Sutcliffe index \\
\hline Stör* & $1992-1996$ & 0.76 \\
Treene* & $1994-1995$ & 0.89 \\
Kielstau I* & $2002-2007$ & 0.80 \\
Kielstau II* & $1998-2004$ & 0.77 \\
\hline
\end{tabular}

* see References in Table 1

change in output can be attributed to a specific change in input (van Griensven et al., 2006). For the Kielstau model setup both sensitivity analyses were conducted considering the absolute change and not the change regarding the measured discharge.

\section{Results}

\subsection{Model performance}

The measured and modelled discharges at the catchment outlets show a good agreement for the four model set-ups of the three study areas. The model performance shows a NashSutcliffe index between 0.76 and 0.89 for the calibration periods (Table 2).

\subsection{Sensitivity analyses of lowland catchment model set- ups}

The modelling results of Stör and Treene show that the most sensitive parameters are the groundwater parameters, ponds and wetlands, soil, drainage and surface runoff. The groundwater parameters turned out to be the most influential factors for lowering the baseflow and improving the simulation of water discharge (see Schmalz et al., 2008b).

For the Kielstau catchment the automatic routine for LHOAT-analysis was used. Table 3 shows the results of the sensitivity analyses using different calibration periods and spatial discretisation. The results show that the largest influence on hydrological modelling have the groundwater and the soil parameters.

\section{Discussion}

\subsection{Dominating processes in lowland catchments}

As shown in Table 3, the largest influence on hydrological modelling results have the groundwater and the soil parameters. The most sensitive parameter in both model set-ups is the threshold water level in shallow aquifer for baseflow (GWQMN). This parameter is followed by the groundwater parameters RCHRG_DP, ALPHA_BF, GW_REVAP and GW_DELAY as well as by the soil parameters SOL_AWC, ESCO and SOL_Z. This list indicates that the water flow in this lowland region is dominated by infiltration, percolation and baseflow due to shallow groundwater. This can be confirmed by field measurements and analyses (Schmalz et al., 2008a).

The different results of the sensitivity analyses of both Kielstau model set-ups depend on the time period of the simulations. Different variabilities of climate parameters and discharge pattern may be caused by exceptional events in the data such as extremely dry summers, heavy rains causing flooding or snow events with snowfall and frozen soil.

\subsection{Comparison to mountainous catchments and low mountain range areas}

This study analyses the model behaviour of SWAT and tests if there is an adequate change of sensitivities between different landscape model-setups. Thus we compared the results of the lowland model set-ups to different mountainous and low mountain range catchment model set-ups. First the results of the Xiangxi catchment in China with a size of $3000 \mathrm{~km}^{2}$ were analysed. Köplin (2008) used the SWAT model (version 2005, ArcView) and achieved a Nash-Sutcliffe index of 0.75 for the calibration period 1977-1979. Within the automatic sensitivity analysis 27 parameters were tested by default. The six most sensitive parameters according to the objective function (sum of the squares of the residuals) were calibrated in the automatic calibration. Köplin (2008) found 
Table 3. Results of the sensitivity analyses of two different model set-ups of Kielstau catchment $\left({ }^{*}\right.$ Kielstau I, ${ }^{* *}$ Kielstau II; see References in Table 1). Processes classified by colours: Blue $=$ groundwater, brown $=$ soil, green $=$ runoff, turquoise $=$ channel, grey $=$ snow.

\begin{tabular}{|l|l|l|l|l|}
\hline Rank & Variables* & Legend to $*$ & Variables** & Legend to ** \\
\hline 1 & GWQMN & $\begin{array}{l}\text { Threshold water level in } \\
\text { shallow aquifer for } \\
\text { baseflow }\end{array}$ & GWQMN & $\begin{array}{l}\text { Threshold water level in } \\
\text { shallow aq. for baseflow }\end{array}$ \\
\hline 2 & RCHRG_DP & $\begin{array}{l}\text { Aquifer percolation } \\
\text { coefficient }\end{array}$ & SOL_AWC & $\begin{array}{l}\text { Available water capacity of } \\
\text { the soil layer }\end{array}$ \\
\hline 3 & ALPHA_BF & $\begin{array}{l}\text { Baseflow recession } \\
\text { constant }\end{array}$ & RCHRG_DP & Aquifer percolation coefficient \\
\hline 4 & ESCO & $\begin{array}{l}\text { Soil evaporation } \\
\text { compensation factor }\end{array}$ & GW_REVAP & Revap coefficient \\
\hline 5 & SOL_AWC & $\begin{array}{l}\text { Available water capacity } \\
\text { of the soil layer }\end{array}$ & ALPHA_BF & Baseflow recession constant \\
\hline 6 & GW-DELAY & $\begin{array}{l}\text { Delay time for aquifer } \\
\text { recharge }\end{array}$ & ESCO & $\begin{array}{l}\text { Soil evaporation compensation } \\
\text { factor }\end{array}$ \\
\hline 7 & SOL_Z & $\begin{array}{l}\text { Depth from soil surface to } \\
\text { bottom of layer }\end{array}$ & GW-DELAY & $\begin{array}{l}\text { Delay time for aquifer } \\
\text { recharge }\end{array}$ \\
\hline 8 & GW_REVAP & $\begin{array}{l}\text { Revap coefficient } \\
\text { Depth from soil surface to } \\
\text { bottom of layer }\end{array}$ & SOL_Z & $\begin{array}{l}\text { Melt factor for snow on June } \\
\text { 21 }\end{array}$ \\
\hline 9 & CH_K2 & $\begin{array}{l}\text { Effective hydraulic } \\
\text { conductivity in main } \\
\text { channel alluvium }\end{array}$ & SMFMX \\
\hline 10 & SOL_K & $\begin{array}{l}\text { Saturated hydraulic } \\
\text { conductivity }\end{array}$ & SMTMP & Snow melt base temperature \\
curface runoff lag & SURLAG & Surface runoff lag coefficient \\
\hline 11 & SURLAG & $\begin{array}{l}\text { SCS runoff curve number } \\
\text { for moisture condition }\end{array}$ & CH_K2 & $\begin{array}{l}\text { Effective hydraulic } \\
\text { conductivity in main channel } \\
\text { alluvium }\end{array}$ \\
\hline 12 & CN2 & & & \\
\hline
\end{tabular}

that the largest influence on the hydrologic modelling was induced by surface runoff, soil and land use. Surface runoff, expressed by the runoff curve number and the surface runoff lag coefficient, is the most sensitive process in this catchment. In addition soil parameters are very important and take six of the first ten ranks (Table 4).

Lenhart et al. (2002) used a simple structured artificial catchment characterised as a low mountain range catchment. They considered 44 separate input parameters which were varied twice by an increment $\Delta x$ (here: $\Delta x=10 \%$ of the initial value of the respective parameter) and divided the results into four sensitivity classes. For the runoff only during summer a very high sensitivity was achieved by the maximum stomatal conductance. For the surface runoff a very high sensitivity was obtained by the depth of bottom layer, bulk density and available water capacity and only during summer by the SCS curve number, the maximum stomatal conductance, the maximum leaf area index and the base temperature. For this low mountain range catchment soil and crop parameters are most sensitive.

Van Griensven et al. (2006) set up the SWAT model for the Sandusky River basin, Ohio $\left(3240 \mathrm{~km}^{2}\right)$ and for the Upper North Bosque river catchment, Texas $\left(932 \mathrm{~km}^{2}\right.$; elevation in the catchment ranges from 305 to $496 \mathrm{~m}$ ). The results for Sandusky river basin identify important parameters for stream flow that cover mainly runoff (CN2, SURLAG), but also snow (SMFMX, SFTMP, TIMP, SMTMP, SMFMN) and soil (SOL_Z, SOL_AWC) processes as well as groundwater
(GWQMN, ALPHA_BF) and channel (CH_K2) processes. For the Upper North Bosque river catchment, the most important parameters represented runoff (CN2, SURLAG, CANMX), followed by soil (SOL_AWC, ESCO, SOL_Z) and groundwater (GWQMN), and also geomorphology (SLSUB$\mathrm{BSN})$ processes.

Ndomba et al. (2008) set up a model for the River Kikuletwa catchment in Tanzania with an area of $7280 \mathrm{~km}^{2}$. The River Kikuletwa drains the Mount Meru through the Shambarai swamps and joins three other rivers to form the main River Kikuletwa. Results of the parameter screening using the ranking procedure indicated that $\mathrm{CN} 2$ was identified as very important while SURLAG, GWQMN, RCHRG_DP, SLOPE and SOL Z $Z$ were important.

Schuol et al. (2008) modelled a basin in West Africa covering an area of 4 million $\mathrm{km}^{2}$ with a great variability of climate, topography and land cover. They found out that the most sensitive parameter was $\mathrm{CN} 2$ indicating surface runoff. The other important parameters represented soil (ESCO, SOL_AWC, SOL_Z, SOL_K), groundwater (GWQMN, GW_REVAP, RCHRG_DP), surface runoff (SURLAG) and channel (CH_K2) processes.

The above mentioned studies of mountainous or low mountain range catchments show that the most sensitive parameters were the surface runoff parameters especially $\mathrm{CN} 2$, the SCS runoff curve number for moisture conditions, but also SURLAG (Surface runoff lag coefficient) and CANMX (maximum canopy storage). The parameter $\mathrm{CN} 2$ was most 
Table 4. Results of the sensitivity analysis of Xiangxi catchment (Köplin, 2008). Processes classified by colours: Blue $=$ groundwater, brown $=$ soil, green $=$ runoff, turquoise $=$ channel, grey $=$ snow .

\begin{tabular}{|l|l|l|}
\hline Rank & Variables & Legend \\
\hline 1 & CN2 & SCS runoff curve number for moisture condition \\
\hline 2 & CH_K2 & Effective hydr. conductivity in main channel alluvium \\
\hline 3 & SURLAG & Surface runoff lag coefficient \\
\hline 4 & ALPHA_BF & Baseflow recession constant \\
\hline 5 & CANMX & maximum canopy storage \\
\hline 6 & SOL_ALB & moist soil albedo \\
\hline 7 & ESCO & Soil evaporation compensation factor \\
\hline 8 & SOL_Z & Depth from soil surface to bottom of layer \\
\hline 9 & SOL_AWC & Available water capacity of the soil layer \\
\hline 10 & BIOMIX & Biological mixing efficiency \\
\hline 11 & SMTMP & Snow melt base temperature \\
\hline 12 & SMFMX & Melt factor for snow on 21 June \\
\hline
\end{tabular}

sensitive - independent of the different catchment sizes and climate conditions. Different soil and groundwater parameters turned out to be also sensitive but there is no clear trend. The most sensitive soil parameters were SOL Z (depth from soil surface to bottom of layer), SOL_AWC (available water capacity of the soil layer) and ESCO (soil evaporation compensation factor). The most sensitive groundwater parameters were GWQMN (threshold water level in shallow aquifer for baseflow), ALPHA_BF (baseflow recession constant) and RCHRG_DP (aquifer percolation coefficient).

In comparison to the Kielstau lowland catchment, differences are to be found: Flow processes in mountainous or low mountain range catchments are more dominated by topography causing surface runoff. In lowland areas with flat topography water flow is dominated by infiltration and the interaction between groundwater and surface water. Thus, the model results show highest sensitivities for groundwater and soil parameters.

\section{Conclusions}

Lowland areas are characterised by specific properties, such as flat topography, low hydraulic gradients, shallow groundwater, and high potential for water retention in peatland and lakes. Sensitivity analyses with the river basin model SWAT were carried out analysing North German lowland catchments to identify the dominant hydrological characteristics. The results show that groundwater and soil parameters were found to be most sensitive in the studied lowland catchments and they turned out to be the most influential factors on simulated water discharge. This indicates that the water flow in this lowland region is dominated by infiltration, percolation and baseflow due to shallow groundwater. In lowland areas with flat topography water flow is dominated by infiltration and the interaction between groundwater and surface water. Thus, the model results show highest sensitivities for groundwater and soil parameters.

In contrast, many studies of mountainous or low mountain range catchments show that the most sensitive parameters were the runoff parameters. The surface runoff parameter CN2 was most sensitive - independent of the different catchment sizes and climate conditions. Flow processes in mountainous or low mountain range catchments are more dominated by topography causing surface runoff.

The parameter sensitivity of the SWAT model depends on climate, land use, topography and soil types, meaning that sensitivity results are not transferable between catchments or a generalisation within a larger basin is limited. Thus a sensitivity analysis needs to be conducted separately for each study catchment. Van Griensven et al. (2006) state that also interior sites show different ranks for the parameters dependent on the physical characteristics of sub-basins.

In future, further analyses and simulation runs can improve the knowledge about model behaviour and sensitivities. E.g. a comparison of the impact of GWQMN regarding the results of discharge simulations (best and worst model performance) would improve the knowledge about the significance of this parameter. Also a further discussion about the potential ambiguity of the parameters could be added. 
Edited by: B. Schmalz, K. Bieger, and N. Fohrer

Reviewed by: M. Wegehenkel and another anonymous referee

\section{References}

Arnold, J. G., Srinivasan, R., Muttiah, R. S., and Williams, J. R.: Large area hydrologic modelling and assessment, Part I: model development, J. Am. Water Resour. Assoc., 34(1), 73-89, 1998.

Dey, T.: Räumlich differenzierte Einzugsgebietsmodellierung für den tidefreien Bereich der Treene. Diploma Thesis, Ecology Centre, Kiel University, Germany. http://www.hydrology. uni-kiel.de/lehre/abschlussarbeiten/da_tdey.pdf, 2004.

Dey, T., Horn, A., Hörmann, G., and Fohrer, F.: Räumlich differenzierte Einzugsgebietsmodellierung am Beispiel des tidefreien Bereichs der Treene. In: Neue Methodische Ansätze zur Modellierung der Wasser- und Stoffumsätze in Großen Einzugsgebieten (7. Workshop zur großskaligen Modellierung in der Hydrologie, München, November 2003) editedd by: Ludwig, R., Reichert, D., and Mauser, W., Kassel University Press, Kassel, Germany, 111-122, 2004.

Di Luzio, M., Srinivasan R., Arnold J. G., and Neitsch, S. L.: Arcview Interface for SWAT2000 - User's Guide. Report TR-193, Texas Water Resources Institute, College Station, Texas, 2002.

Dobslaff, N.: GIS-basierte Modellierung von Wasserhaushalt und Abflussbildung am Beispiel des Einzugsgebietes der oberen Stör. Diploma Thesis, Ecology Centre, Kiel University, Germany, http://www.hydrology.uni-kiel.de/lehre/abschlussarbeiten/ da_dobslaff.pdf, 2005.

Fohrer, N., Schmalz, B., Tavares, F., and Golon, J.: Ansätze zur Integration von landwirtschaftlichen Dränagen in die Modellierung des Landschaftswasserhaushalts von mesoskaligen Tieflandeinzugsgebieten. Hydrologie und Wasserbewirtschaftung, 51(4), 164-169, 2007.

Habeck, A., Krysanova, V., and Hattermann, F.: Integrated analysis of water quality in a mesoscale lowland basin, Adv. Geosci., 5, 13-17, 2005, http://www.adv-geosci.net/5/13/2005/.

Hamby, D. M.: A review of techniques for parameter sensitivity analysis of environmental models, Environ. Monit. Assess. 32, 135-154, 1994.

Hattermann, F. F., Krysanova, V., Habeck, A., and Bronstert, A.: Integrating wetlands and riparian zones in river basin modelling, Ecol. Modell., 199(4), 379-392, 2006.

Hattermann, F. F., Krysanova, V., and Hesse, C.: Modelling wetland processes in regional applications, Hydrol. Sci. J., 53(5) Special issue: Advances in Ecohydrological Modelling with SWAT, 1001-1013, 2008.

Hesse, C., Krysanova, V., Päzolt, J., and Hattermann, F. F.: Ecohydrological modelling in a highly regulated lowland catchment to find measures for improving water quality, Ecol. Modell., 218, $135-148,2008$

Kieckbusch, J., Schrautzer, J., and Trepel, M.: Spatial heterogeneity of water pathways in degenerated riverine peatlands, Basic Appl. Ecol., 7, 388-397, 2006.

Kiesel, J., Fohrer, N., and Hering, D.: Integrierte Modellierung zur Beschreibung aquatischer Habitate. Tag der Hydrologie 2008, 27./28.03.2008, Hannover, Germany, Poster, 2008.
Köplin, N.: Hydrologische Modellierung der Effekte des Landnutzungswandels auf den Wasserhaushalt im XiangxiEinzugsgebiet (Drei-Schluchten-Damm) mit SWAT. Diploma thesis Ecology Centre Kiel University, Germany, http://www.hydrology.uni-kiel.de/lehre/abschlussarbeiten/ 2008_koeplin_xiangxi.pdf, 82 pp. 2008.

Krause, S. and Bronstert, A.: The impact of groundwater - surface water interactions on the water balance of a mesoscale lowland river catchment in northeastern Germany, Hydrol. Proc., 21, 169-184, 2007.

Krause, S., Bronstert, A., and Zehe, E.: Groundwater - surface water interactions in a north German lowland floodplain - implications for the river discharge dynamics and riparian water balance, J. Hydrol. 347, 404-417, 2007a.

Krause, S., Jacobs, J., and Bronstert, A.: Modelling the impacts of land-use and drainage density on the water balance of a lowland floodplain landscape in northeast Germany, Ecol. Modell., 200(3-4), 475-492, 2007b.

Lam, Q. D., Schmalz, B., and Fohrer, N.: Ecohydrological modelling of the hydrology of a North German lowland catchment. 12. Workshop Großskalige Hydrologische Modellierung, 12-14 November 2008 in Salzau, Germany, Poster, http://www.hydrology.uni-kiel.de/lehre/publikationen/poster/ 2008_lam-ghm08.pdf, 2008.

Lam, Q. D., Schmalz, B., and Fohrer, N.: Ecohydrological modelling of water discharge and nitrate loads in a mesoscale lowland catchment, Germany, Adv. Geosci., this special volume, 2009.

LVA S-H: Digitales Geländemodell DHM50 für SchleswigHolstein, Gitterweite $50 \times 50 \mathrm{~m}$. Landesvermessungsamt Schleswig-Holstein, Kiel, Germany, 1995.

Lenhart, T., Eckhardt, K., Fohrer, N., and Frede, H.-G.: Comparison of two different approaches of sensitivity analysis, Phys. Chem. Earth, 27, 645-654, 2002.

Ndomba, P., Mtalo, F., and Killingtveit, A.: SWAT model application in a data scarce tropical complex catchment in Tanzania, Phys. Chem. Earth, 33, 626-632, 2008.

Neitsch, S. L., Arnold, J. G., Kiniry, J. R., Srinivasan, R., and Williams, J. R.: Soil and Water Assessment Tool - User's Manual. Version 2000. Blackland Research \& Extension Center, Temple, Texas, USA, 2002a.

Neitsch, S. L., Arnold, J. G., Kiniry, J. R., Srinivasan, R., Williams, J. R., and King, K. W.: Soil and Water Assessment Tool - Theoretical Documentation. Version 2000. Blackland Research \& Extension Center, Temple, Texas, USA, 2002b.

Neitsch, S. L., Arnold, J. G., Kiniry, J. R., and Williams, J. R.: Soil and Water Assessment Tool - Theoretical Documentation, Version 2005. Texas, USA, 2005.

Schmalz, B., Tavares, F., and Fohrer, N.: Assessment of nutrient entry pathways and dominating hydrological processes in lowland catchments. Adv. Geosci., 11, http://www.adv-geosci.net/ 11/107/2007/adgeo-11-107-2007.pdf, 107-112, 2007.

Schmalz, B., Springer, P., and Fohrer, N.: Interactions between near-surface groundwater and surface water in a drained riparian wetland. Groundwater-Surface Water Interaction: Process Understanding, Conceptualization and Modelling, edited by: Abesser, C., Wagener, T., and Nuetzmann, G., IAHS Publ., 321, 21-29, 2008a.

Schmalz, B., Tavares, F., and Fohrer, N.: Modelling hydrological lowland processes in mesoscale river basins with SWATCapabil- 
98 B. Schmalz and N. Fohrer: Comparing model sensitivities of different landscapes using the ecohydrological SWAT model

ities and challenges, Hydrol. Sci. J., 53(5), 989-1000, 2008 b.

Schuol, J., Abbaspour, K. C., Srinivasan, R., and Yang, H.: Estimation of freshwater availability in the West African sub-continent using the SWAT hydrologic model, J. Hydrol., 352, 30-49, 2008.

Sophocleous, M.: Interactions between groundwater and surface water: the state of the science, Hydrogeol. J., 10, 52-67, 2002. van Griensven, A., Meixner, T., Grunwald, S., Bishop, T., Diluzio, A., and Srinivasan, R.: A global sensitivity analysis tool for the parameters of multi-variable catchment models, J. Hydrol., 324(1-4), 10-23, 2006.

Venohr, M.: Einträge und Abbau von Nährstoffen in Fließgewässern der oberen Stör, Diploma Thesis, Ecology Centre, Kiel University, 2000. 